\title{
PERBANDINGAN KADAR TRIGLISERIDA DARAH PADA PRIA PEROKOK DAN BUKAN PEROKOK
}

\author{
${ }^{1}$ Fandry Johnkun Wowor \\ ${ }^{2}$ Shane H. R Ticoalu \\ ${ }^{2}$ Djon Wongkar
}

\author{
${ }^{1}$ Kandidat Skripsi Fakultas Kedokteran Universitas Sam Ratulangi Manado \\ ${ }^{2}$ Bagian Anatomi Histologi Fakultas Kedokteran Universitas Sam Ratulangi Manado \\ fandrywowor@yahoo.com
}

\begin{abstract}
Smoking is a risk factor for atherosclerotic disease. Nicotine contained in cigarette smoke can increase lipolysis and free fatty acid concentrations that affect blood lipid profile triglyceride one that smokers had higher triglyceride levels than in non-smokers. Objective: To compare blood levels of triglycerides in male smokers and nonsmokers. Methods: This type of research is an observational study using cross-sectional research design. Result: Statistically determined that there were significant differences between blood triglyceride levels in male smokers and nonsmokers with p value was ,026. Conclusion: Statistically significant difference between blood triglyceride levels in male smokers and nonsmokers
\end{abstract}

Keywords: blood triglyceride levels, smokers, non-smokers.

\begin{abstract}
Abstrak: Merokok merupakan faktor risiko timbulnya penyakit aterosklerosis. Nikotin yang terkandung dalam asap rokok dapat meningkatkan lipolisis dan konsentrasi asam lemak bebas yang mempengaruhi profil lemak darah salah satunya trigliserida sehingga perokok mempunyai kadar trigliserida yang lebih tinggi dari pada bukan perokok. Metode: Jenis penelitian yang digunakan yaitu penelitian observasional dengan menggunakan desain penelitian cross sectional. Hasil: Secara statistik ditetapkan bahwa terdapat perbedaan yang bermakna antara kadar trigliserida darah pada pria perokok dan bukan perokok dengan $p=$,026. Simpulan: Secara statistik terdapat perbedaan yang bermakna antara kadar trigliserida darah pada pria perokok dan bukan perokok
\end{abstract}

Kata kunci: Kadar trigliserida darah, perokok, bukan perokok.

Bersamaan dengan adanya peradaban manusia tembakau sudah dikenal manusia. Tembakau dikonsumsi manusia dengan berbagai cara dan yang paling umum ditemui ialah tembakau dikonsumsi sebagai rokok. Merokok yang berkepanjangan akan memberi dampak timbulnya gangguan kesehatan seperti timbulnya kanker, timbulnya penyakit kardiovaskular dan timbulnya penyakit pada paru. ${ }^{1}$

Riset kesehatan dasar 2010 secara nasional, rata-rata jumlah batang rokok yang dihisap tiap hari oleh lebih dari separuh (52,3\%) perokok adalah 1-10 batang dan sekitar 20 persen sebanyak 11-20 batang per hari. Penduduk yang merokok 1-10 batang per hari paling tinggi dijumpai di Maluku (69,4\%), disusul oleh Nusa Tenggara Timur (68,7\%), Bali (67,8\%), DI Yogyakarta (66,3\%), dan Jawa Tengah (62,7\%). Sedangkan persentase penduduk merokok dengan rata-rata 21-30 batang per hari tertinggi di Provinsi Aceh (9,9\%) dikuti Kepulauan Bangka Belitung (8,5\%) dan Kalimantan Barat (7,4\%). Persentase penduduk merokok dengan rata-rata lebih dari 30 batang per hari tertinggi di Provinsi Kepulauan Bangka Belitung (16,2\%), Kalimantan Selatan (7,9\%) serta Aceh dan Kalimantan Tengah (5,4\%). ${ }^{2}$ 
Merokok merupakan faktor risiko timbulnya penyakit aterosklerosis., ${ }^{1,3}$ Merokok dapat mempengaruhi faktor-faktor fisiologis, patologis, hematologis dan metabolik yang masing-masing faktor tadi dapat berperan pada mulainya, perkembangannya dan akhirnya timbul ateroskelrosis. Dengan demikian penghentian merokok akan mengurangi progresivitas aterosklerosis serta morbiditas dan mortalitasnya. ${ }^{1}$

Pada rokok telah ditemukan sekitar 4.000 jenis bahan kimia beracun diantaranya Nikotin, tar, dan karbon monoksida. ${ }^{4}$ Nikotin yang terkandung dalam asap rokok dapat meningkatkan lipolisis dan konsentrasi asam lemak bebas yang mempengaruhi profil lemak darah salah satunya trigliserida sehingga perokok mempunyai kadar trigliserida yang lebih tinggi dari pada bukan perokok. ${ }^{5}$

Trigliserida adalah lipid utama di timbunan lemak dan di dalam makanan. Peran senyawa ini dalam transpor dan penyimpanan lipid serta pada terjadinya berbagai penyakit seperti obesitas, diabetes, dan hiperlipoproteinemia. Trigliserida dipakai dalam tubuh terutama untuk meyediakan energi bagi proses metabolik, suatu fungsi yang hampir sama dengan fungsi karbohidrat. ${ }^{6,7}$ Peningkatan kadar trigliserida diatas batas normal disebut hiperlipidemia. ${ }^{8}$ Peningkatan kadar trigliserida di dalam darah merupakan salah satu faktor risiko penyakit jantung koroner. ${ }^{9}$

Di kalangan mahasiswa merokok sudah menjadi kebiasaan sehari-hari. Oleh karena itu penulis tertarik untuk membandingkan kadar trigliserida darah perokok dan bukan perokok pada mahasiswa semester 7 tahun ajaran 2012-2013 Fakultas Kedokteran Universitas Sam Ratulangi Manado.

\section{METODE PENELITIAN}

Jenis penelitian merupakan penelitian observasional dengan menggunakan desain penelitian Cross Sectional. Waktu penelitian dilakukan pada tanggal 5, 6, dan 12 desember 2012, Lokasi penelitian dilaksanakan di gedung Pertamina Universitas Sam Ratulangi Manado dan pemeriksaan sampel darah dilakukan di Laboratorium Medistar Manado. Populasi penelitian ini yaitu mahasiswa pria semester 7 tahun ajaran 2012-2013 yang berjumlah 150 orang yang aktif kuliah. Teknik pengambilan sampel pada penelitian ini yaitu dengan menggunakan teknik purposive sampling, perokok dan bukan perokok didapatkan dengan menggunakan kuesioner. Kriteria inklusi yaitu laki-laki dan perokok (minimal mengonsumsi rokok sebanyak 10 batang setiap hari) dan mahasiswa aktif kuliah. Kriteria eksklusi yaitu mahasiswa sedang sakit, menolak untuk diperiksa, adnya riwayat penyakit diabetes, hipertensi, ginjal, hepatitis, obesitas, dan hanya sekali merokok. Besar sampel untuk penelitian ini berjumlah 56 orang yang memenuhi kriteria. Alat pada penelitian ini yaitu semprit dan lembaran kuesioner, bahan pada penelitiaan ini reagen trigliserida, serum darah, kapas, alkohol, dan plester. Pemeriksaan sampel darah dilakukan oleh Laboratorium Medistar Manado. Pada penelitian ini menggunakan uji alternatif dari uji T yaitu Mann-Whitney.

\section{HASIL PENELITIAN}

Subjek penelitian berjumlah 56 pria yang terdiri dari 28 perokok dan 28 bukanPerokok yang memenuhi kriteria pada mahasiswa semester 7 tahun ajaran 20122013 Fakultas Kedokteran Universitas Sam Ratulangi Manado Subjek penelitian terdiri dari pria yang berusia 19-23 tahun. Jumlah subjek dalam penelitian sebanyak 56 orang dengan persentase terbesar usia 21 tahun sebanyak 25 orang (45\%) dan terkecil usia 19 dan 23 tahun sebanyak 3 orang (5\%). 20 tahun sebanyak 13 orang (23\%) dan 22 tahun sebanyak 12 orang (21\%). Berdasarkan tinggi badan persentase terbesar 161-170 cm sebanyak 28 orang (50\%) dan terkecil 181-190 cm sebanyak 3 orang (5\%). 171-180 cm sebanyak 20 orang (36\%) dan 151-160 cm sebanyak 5 orang (9\%). Berdasarkan berat badan persentase terbesar $61-70 \mathrm{~kg}$ sebanyak 28 orang (50\%) dan terkecil 71-80 kg sebanyak 4 orang (7\%). 41-50 kg sebanyak 5 orang (9\%) dan 51-60 kg sebanyak 19 orang (34\%). 
Pada 28 subjek penelitian pria perokok nilai rata-rata kadar trgliserida darah 108,68 (mg/dL) dengan standar deviasi 55,230. Nilai maksimum 272 (mg/dL) dan nilai minimum 42 (mg/dL). Pada 28 subjek penelitian pria bukan perokok nilai rata-rata kadar trgliserida darah 77,93 (mg/dL) dengan standar deviasi 34,080. Nilai maksimum 153 (mg/dL) dan nilai minumum 20 (mg/dL).

\section{Uji Persyaratan Analisis}

Pengujian persyaratan analisis yang digunakan dalam penelitian ini adalah uji Kolmogorov-Smirnov. Perhitungan dilakukan sebelum data dilakukan pengujian hipotesis. Berdasarkan hasil perhitungan diperoleh hasil uji normalitas sebagai berikut:

Hasil uji normalitas

\begin{tabular}{ccc}
\hline Trigliserida & $\begin{array}{c}\text { Kolmogorov- } \\
\text { smirnov (a) P- } \\
\text { Value }\end{array}$ & Keterangan \\
\hline $\begin{array}{c}\text { Perokok dan } \\
\text { bukan }\end{array}$ &, 004 & Tidak normal \\
perokok & & \\
\hline
\end{tabular}

Berdasarkan hasil perhitungan menggunakan uji Kolmogorov-Smirnov dari kadar trigliserida darah pada perokok dan bukan perokok mempunyai nilai probabilitas (p-value) sebesar ,004. Suatu data dinyatakan berdistribusi normal jika nilai probabilitasnya lebih besar dari 0,05. Hasil uji menunjukkan nilai probabilitas kadar trigliserida darah pada perokok dan bukan perokok sebesar ,004 maka dapat disimpulkan bahwa data berasal dari popoluasi yang berdistribusi tidak normal, oleh karena distribusi data tidak normal digunakan uji alternatif dari uji $\mathrm{T}$ yaitu Mann-Whitney.

\section{BAHASAN}

Usia subjek penelitian ini terdiri dari pria berusia 19 samapi 23 tahun. Usia 21 tahun merupakan usia terbanyak pada penelitian ini yaitu 25 orang dengan persentase sebanyak 45\%. Tinggi badan subjek penelitian ini terbanyak pada tinggi badan 161-170 cm yaitu sebanyak 28 orang dengan persentase 50 dan berat badan subjek penelitian ini terbanyak pada berat badan 61-70 kg yaitu sebanyak 28 orang dengan persentase $50 \%$

Hasil kadar trigliserida darah pada 28 pria perokok didapatkan nilai rata-rata kadar trgliserida darah 108,68 (mg/dL) dengan standar deviasi 55,230. Nilai maksimum kadar trigliserida darah pada pria perokok sebanyak 272 (mg/dL) dan nilai minmum kadar trigliserida darah pada pria perokok sebanyak 42 (mg/dL), sedangkan pada 28 pria bukan perokok didapatkan nilai ratarata kadar trigliserida darah 77,93 (mg/dL) dengan standar deviasi 34,080. Nilai maksimum kadar trigliserida darah pada pria yang bukan perokok sebanyak 153 (mg/dL) dan nilai minimum kadar trigliserida darah pada pria yang tidak merokok sebanyak 20 (mg/dL).

Berdasarkan hasil analisa data dan pengujian hipotesis yang didapatkan bahwa dalam penelitian ini mempunyai hubungan yang kuat dengan teori yang ada bahwa nikotin yang terkandung dalam asap rokok dapat menigkatkan lipolisis dan konsentrasi asam lemak bebas yang mempengaruhi profil lemak darah salah satunya trigliserida sehingga perokok mempunyai kadar trigliserida yang lebih tinggi dari pada bukan perokok. ${ }^{5}$ Pada penelitian ini didapatkan perbedaan kadar trgliserida darah pada pria perokok dan pria bukan perokok dimana pria perokok mempunyai kadar trigliserida yang lebih tinggi dari pada pria bukan perokok.

Penelitian yang dilakukan Guven A dan Tolun F di Baskent University School of Medicine, Dapartment of Cardiology, Konya Turki dengan judul efek dari tembakau tanpa asap "bubuk Maras" dan penggunaan tembakau pada oksida nitrat dan parameter risiko kardiovaskular didapatkan kolestrol darah salah satunya trigliserida secara signifikan lebih tinggi dalam bubuk maras dan kelompok perokok dibandingkan dengan kelompok yang tidak 
merokok (p,0,001). Dimana dalam studi tersebut 48 pengguna bubuk maras, 50 perokok dan 45 tidak merokok diambil darahnya masing-masing kemudian sampel darah dikumpulkan dan parameter hematologi dan parameter lipid diukur. ${ }^{10}$

Peneltian yang dilakukan Gokulakrisnan dan kawan-kawan di Periyar University Salam, Tamil Nadu, India pada tikus dewasa jantan yang diberi paparan asap rokok didapatkan peningkatan yang signifikan dari kadar trigliserida darah pada tikus yang diberikan paparan asap rokok ${ }^{11}$ begitu juga penelitian yang dilakukan Yon C dan kawan-kawan di Seoul National University, Seoul, Korea Selatan didapatkan bahwa kelompok merokok lebih mudah terkena risiko CVD karena mereka yang merokok memiliki peningkatan tekanan darah $(\mathrm{P}<0,01)$ dan kadar kolestrol salah satunya trigliserida $(\mathrm{P}<0,05){ }^{12}$

Penelitian yang dilakukan Swierszcz dan kawan-kawan di Polandia pada 60 pasien dengan AVS dan 14 kontrol pemeriksaan echocardiograpic diawal dan bulan ke-12 pengamatan dimana rasio perokok lebih tinggi pada kelompok AVS dibandingkan dengan kontrol dan disimpulkan bahwa merokok meningkatkan plasma trigliserida dan lipoprotein ${ }^{13}$ dan penelitian yang dilakukan Chakkarwar VA di india didapatkan juga hasil bahwa noktin yang terkandung dalam asap rokok dapat mengubah profil lipid dengan meningkatkan kadar trigliserida. ${ }^{14}$

Penelitian-penelitian yang dilakukan sebelumnya didapatkan hasil bahwa merokok dapat meningkatkan kadar trigliserida darah. Hasil yang didapatkan pada penelitian ini yaitu ada perbedaan yang bermakna secara statistik antara kadar trigliserida darah pada mahasiswa semester 7 tahun ajaran 2012-2013 Fakultas Kedokteran Universitas Sam Ratulangi Manado yang perokok dan bukan perokok, pada perokok mempunyai kadar trigliserida yang lebih tinggi dari pada bukan perokok. Jadi dapat dsimpulkan dari teori yang ada dan penelitian-penelitian yang dilakukan sebelumnya bahwa ada perbedaan antara kadar trigliserida darah pada perokok dan bukan perokok yang menguatkan penelitian ini, pada perokok mempunyai kadar trigliserida yang lebih tinggi dari pada bukan perokok.

\section{SIMPULAN}

Secara statistik ditetapkan bahwa terdapat perbedaan yang bermakna antara kadar trigliserida darah pada pria perokok dan bukan perokok. Berdasarkan hasil penelitian saran untuk penelitian selanjutnya agar dapat memperbesar sampel yang diteliti.

\section{DAFTAR PUSTAKA}

1. Sudoyo A. W, Seiyohadi B, Alwi I, Simadibrata M, Setiati S. Ilmu penyakit dalam. Jilid III. Jakarta: Interna publishing; 2009 : 2292-2293

2. Badan Penelitian dan Pengembangan Kesehatan Riset Kesehatan Dasar 2010 Kementerian Kesehatan RI 2010 : 403

3. Burns D, Kumar V. Patologi robbins. Edisi 7. Jakarta: Buku kedokteran EGC; 2007: 408

4. Wagner H. L. Nicotine. Cina: Chelsea House Publishers; 2003 : 13

5. Institude of medicine of the national academes. Secondhand smoke exposure and cardiovascular effects. Washington, DC: The national academy press; $2010: 69$

6. Botham K. M, Moyes P. A, Biokimia harper. Edisi 27. Jakarta: Buku kedokteran EGC; 2009 : 217

7. Guyton A. C, Hall J. E. Fisiologi kedokteran. Edisi 11. Jakarta: Buku kedokteran EGC; 2008 : 893,882

8. Price S. A, Wilson L. M. Patofisiologi. Edisi 6. Jakarta: Buku kedokteran EGC; 2005 : 580

9. Lingga L. Sehat dan sembuh dengan lemak. Jakarta: PT elex media komputindo; 2012 : 11

10. Guven A, Tolun F. Effects of smokeless tobacco "Maras powder" use on nitric oxide and cardiovascular risk parameters. Int $\mathrm{J}$ Med Sci [serial online]. 2012 [cited 2013 Jan 12]; 9(9):786-92. Available from: www.ncbi.nlm.nih.gov/pubmed?term=Effec ts+of+smokeless+tabacco+"Maras+powder" +use_on_nitric + oxide+and+cardiovascular+ risk+parameters 
990 Jurnal e-Biomedik (eBM), Volume 1, Nomor 2, Juli 2013, hlm. 986-990

11. Gokulakrisnan A, Javachandran Dare B, Thirunavukkarasu C. Attenuation of the cardiac inflammatory changes and lipid anomalies by (-)-epigallocatechin-gallate in cigarette smoke-exposed rats. Mol Cell Biochem [serial online]. 2011 Aug [cited 2013 Jan 12]; 354(1-2):1-10. Available from:

www.ncbi.nlm.nih.gov/pubmed?term=Atten uation+of +the+cardiac+inflammatory+chan ges+and+lipid+anomalies+by+(-)epigallocatechingallate+in+cigarette+smoke-exposed+rats

12. Yoon C, Goh E, Park SM, Cho B. Effects of smoking cessation and weight gain on cardiovascular disease risk factors in Asian male population. Atherosclerosis [serial online]. 2010 Jan [cited 2013 Jan 12]; 208(1):275-9. Available from:
www.ncbi.nlm.nih.gov/pubmed?term=Effec $\mathrm{t}$ of smoking cessation and weight gain on cardiovascular disease risk factors in Asian male population.

13. Swierszcz J. Dubiel JS, Milewicz T, Sztefko $\mathrm{K}$, Krzysiek J. Smoking, increase in plasma lipoprotein (a) and triglycerides, as well as decresae in plasma HDL-cholesterol concentrations seem to be linked with aortic valve stenosis and its progression. Przeglad Lekarski. 2009; 66(4)159-65.

14. Chakkarwar VA. Fenofibrate attenuates nicotine-induced vascular endothelial dysfunction in the rat. Vascul Pharmacol [serial online]. 2011 Nov-Dec [cited 2013 Jan 20]; 55(5-6):163-8. Available from: http://www.ncbi.nlm.nih.gov/pubmed/21864 717 